\title{
Is the Adoption of IFRS for SMEs an Added Value for the Financial Reporting in Albania?
}

\author{
Elira Hoxha, MSc (PhD Student) \\ Executive Director of National Accounting Council \\ "Blv Bajram Curri" Pall 31, Shk 1, Ap 4, Tirana, Albania \\ elira_hoxha@hotmail.com
}

Doi:10.5901/ajis.2014.v3n3p371

\begin{abstract}
SMEs play a vital role in the economy of a country. As in the other European countries, in Albania the SMEs represent over 97 $\%$ of entities registered in the commercial register. The importance and their contribution to the economy of a country made possible that the international standard setting body, IASB, to devote a special attention to those developing a specific standard aimed to reduce the reporting burdens on these entities. IFRS for SMEs, published in July 2009, it is not mandatory but the adoption of this standard remains a challenge for every country of the world. Most of European countries are still conservative deciding in favor of the application of this standard as prefer their local standards for SMEs. Albania also has its own local accounting standards for such entities, but in circumtances when it aspires to become an EU country, aims to increase foreign investment and tries to incourage doing business in Albania, the adoption of IFRS for SMEs remains a very important decision. The purpose of this paper is to assess whether the adoption of IFRS for SMEs is an added value for financial reporting in Albania. The conclusion will be reached through the evaluation of capability of preparers of financial statements of SMEs, the needs of users of SME financial statements and thecost / benefit analysis.
\end{abstract}

Keywords: SMEs, IFRS for SMEs, financial reporting, users of financial statements, Albania

\section{Background}

\subsection{Introduction}

Small and medium entities play a vital role in the economy of a country. Their growth brings positive effects on the overall economy. As in other European countries, even in Albania, SMEs are the foundation of the economy. Given their business figures, they are categorized in micro, small and medium entities; referring to INSTAT data for 2012 small and medium entities are the economic giant as they represent $97.7 \%$ active entities $(101,917$ out of 104,275 total active entities).

According to their accounting regulation, National Accounting Council is the the regulatory body in Albania, which by law has the task of setting the national accounting standards for these entities. With the exception of the banking sector, that of insurance, subsidiaries of foreign listed entities as well as very large entities, all the other entities apply national accounting standards developed by this regulatory body.

Although since July 2009, the IASB published the International Financial Reporting Standard for Small and Medium Enterprises, designed specially for entities without public interest, European countries generally prefer to apply local standards for such entities.

\subsection{Research problem}

Entities, regardless of their size, are bound to respect the laws of their countries and to prepare financial statements in accordance with the financial reporting framework adopted in their place. When IASB drafted IFRS for SMEs, argued that this standard was framed for all those entities that do not have public interest. The financial statements of SMEs, prepared under IFRS for SMEs offer their users information about the financial position, financial performance and cash flows. A good part of the users of these statements are based on information provided by these statements when it comes to their future decisions economic (IASB, 2009, p. 10-11).

Sice IASB has published IFRS for SMEs and all EU member countries are discussing the adoption of this standard, even Albania should consider this option. It is a matter of fact that NASs are designed in full coherence with full IFRS but Albanian entities as well as Albanian market in general is too much smaller or even negligible comparing to entities and markets of other European countries. Therefore is an actual concern of regulatory organisms in Albania to 
stay under current NASs or to shift toward IFRS for SMEs adoption.

\subsection{Research question}

"Is Albania ready to adopt IFRS for SMEs?" thus requiring an indirect answer to the question "Does the adoption of IFRS for SMEs add any value to the quality of decision-making of users of SMEs financial statements?". More than few arguments will extend the discussion and will be divided it two major groups, the first will include arguments about research subquestion "Is it necessary?" while the second group includes arguments about the other subquestion "Is it possible?".

\section{Literature Review}

This chapter will highlight some of the existing literature finding in the field of research that I have chosen the adoption of IFRS for SMEs. The literature review is divided into three sections. The first section deals with an overall view, the second section deals with the users of financial statements of SMEs and the final section deals with the factors that must be taken into consideration if shifting towards IFRS for SMEs.

\subsection{Overall view}

Globalization, particularly economic globalization is nowadays an undisputed reality. SMEs have been very important in the process of globalization and strengthening worldwide economy, thus accounting information submitted by SMEs is very important. We should know more about aspects related to SMEs, such as who are the users of accounting information, comparability and harmonization of this information. In this context, we should assess the role of a very important actor in this plan, such as compilers of the accounting standards. IFRS for SMEs was published in July 2009.

IFRS for SMEs represents an important step towards global convergence of financial reporting practices of SMEs. This standard will help improve the quality and comparability of financial statements of SMEs worldwide and will be an opportunity for SMEs in terms of their access to the world of finance and funding (Neaga, Mascia \& Pascan, 2009, p. 1). IASB developed IFRS for SMEs considering cost benefit analysis of these standards during their use by entities. It is understood that all principles regarding the recognition, measurement, subsequent assessment, presentation and disclosures are sufficiently simplified compared to full IFRS. Many of the requirements for disclosures are reduced and many issues not related to SMEs have been omitted (Fitzpatrick \& Frank, 2009, p. 50).

\subsection{Financial Statements Users}

In the early literature (a.o. Edwards and Bell, 1961), business managers were considered to be the primary users of accounting information. Later on, the decision-usefulness for external users of financial statements became more important. This connection between financial statements and decision usefulness for users was introduced by the standard setters in the 1970s. At first, this connection was criticised by preparers and academics (a.o. Puxty and Laughlin, 1983).

Ironically, one of the arguments against it was the lack of knowledge concerning the users and their needs. Nevertheless, the decision usefulness concept became accepted and many textbooks and articles now list similar users of financial statements. Sometimes, a distinction is made between direct and indirect users. Riahi-Belkaoui (2004) for example lists the following users: - Direct users: Owners of the corporation and its shareholders; Creditors and suppliers; Management of the firm; Taxing authorities; Labourers in an organization; Customers; - Indirect users: Financial analysts and advisers; The stock exchanges; Lawyers; Regulatory or registration authorities; The financial press and reporting agencies; Trade associations; Labour unions; Competitors; The general public; Governmental departments

The question "Who are the users of financial statements"? has hardly been empirically investigated. The most investigated user groups for listed companies are shareholders, investors and analysts. For non-listed companies, typically bankers are interrogated.

These studies show that financial statements are considered as valuable but not sufficient information sources. Other studies show that the financial statements do not adequately satisfy the information needs of their users. Day (1986) for example argues that investment analysts show a lack of understanding of accounting methods. Bartlett and Chandler (1997) show that many parts of the financial statements are neither well read nor well understood. A more recent study of the International Federation of Accountants (IFAC, 2008) reveals that financial statements have even 
become less useful because they have become too complex for the average reader to understand.

\subsection{Factors to take into consideration whether the move towards IFRS for SMEs}

Before an entity starts to apply IFRS for SMEs, management should consider the feasibility in terms of some specific factors which determine long-term success of the entity. Willingness of the preparers of these financial statements should be the first to be taken in consideration along with the suitability of the time for the transition from local standards to IFRS for SMEs.

Also, training the staff of the entities in a timely and appropriate manner is very important, but always before the adoption of IFRS for SMEs.

Internal control should be assessed in terms of the impact that would the modifications have on already existing control system, in terms of the effectiveness of the latter. Ways and new forms of communication should be designed in such a way as to minimize the shocking surprises that come as a result of something entirely new for investors, creditors, customers and suppliers. For existing contracts or loan agreements, commitments must be made by a renegotiation after switching to another based reporting has its effects on the financial information (Munter, Anderson \& Mellentine, 2009, p. 2).

Different countries have different laws on taxation, so the preparation of financial statements under IFRS for SMEs may differ from what is required from tax authorities. SMEs that implement IFRS for SMEs can not be completely in line with what is required them from the tax authorities of their countries. Manipulations or changes in tax laws depend on the tax authorities (IASB, 2009, p. 7-8).

\section{Methodology}

The choice of the subject of this paper relies on the controversial issue of the adoption of IFRS for SMEs in Albania. Research strategy will be a qualitative research method in order to deepen the subjectivity, experience and internal reaction of selected sample in the study. The paper is conceived as a social survey with a cross-sectional design. "Crosssectional design involves the collection of data on more than one case and at a single point in time in order to collect a body of quantitative or quantifiable data in connection with two or more variables, which are then examined to detect patterns of association" (Bryman \& Bell, 2007, p. 55). When a number of cases are looked at one single point in time, then it is termed as a survey".

Research instruments will be (a) Tables of Concordance aiming to evaluate technical aspects of efectiviness of shifting toward IFRS for SMEs (first one to compare each of NASs with the IFRS for SMEs sections and to highlight the differences between these two sets of reporting, than second one to compare NASs with the provisions of Directive 2013/34/EU to understand whether are NASs in line with the Directive or not and so understanding better if IFRS for SMEs goes closer to that Directive), (b) questionnaires and interviews to evaluate the perception of individuals and groups in regard of the need, possibility and adequacy of adopting IFRS for SMEs. To support the analysis and conclusions of the paper will be assembled primary data through concordance tables, questionnaires and interviews as well as secondary data through literature review.

The survey sample in the study will consist of two target groups: (a) the preparers of financial statements of SMEs (b) the users of financial information of these statements.

\section{Empirical Findings, Analysis and Discussions}

In this chapter will be described the empirical findings in accordance with the theoretical framework presented in the relevant section of this paper. Analysis and discussion will be about the implications and the assessment of factors affecting the decision on the adoption of IFRS for SMEs in Albania. More specifically the analysis will focus technical and economic context.

\subsection{Table of Concordance - Differences between the NAS and IFRS for SMEs}

From the concordance table between NASs and IFRS for SMEs, where paragraphs of both sets of financial reporting were respectively compared, resulted a list of differences as follows: 
Table 1. Concordance table between NASs and IFRS for SMEs

\begin{tabular}{|c|c|}
\hline $\begin{array}{r}\text { NAS } 1 \\
\text { "Framework" }\end{array}$ & The concept of comprehensive income is missing. \\
\hline $\begin{array}{l}\text { NAS } 2 \text { "Presentation of } \\
\text { Financial statements" }\end{array}$ & $\begin{array}{l}\text { The statement for comprehensive income is missing; Different nominaton for financial statements; } \\
\text { Balance sheet - Statement of Financial Position; Statement of revenues and expenses - Statement of } \\
\text { financial performance }\end{array}$ \\
\hline $\begin{array}{l}\text { NAS } 3 \text { "Financial } \\
\text { Instruments" }\end{array}$ & $\begin{array}{l}\text { There are all included in a single standard (simple and complex instruments), differently from the IFRS for } \\
\text { SMEs where there are two separate sections. Also, differently from IFRS for SMEs, the fair value model } \\
\text { is allowable for the subsequent assessment of the simple financial instruments. }\end{array}$ \\
\hline NAS 4 "Inventories" & $\begin{array}{l}\text { It is still used the term 'net realizable value' instead of 'selling price after deduction of costs of completion } \\
\text { and selling'. }\end{array}$ \\
\hline $\begin{array}{l}\text { NAS } 5 \text { "Fixed and } \\
\text { intangible assets" }\end{array}$ & $\begin{array}{l}\text { Development costs are treated as intangible assets; Borrowing costs have two options to account for - as } \\
\text { period expenses or capitalized in the cost of qualified assets; Goodwill - is tested for impairment; Section } \\
\text { of investment property is missing; Still allowable the model of property revaluation; }\end{array}$ \\
\hline $\begin{array}{l}\text { NAS } 9 \text { "Bisiness } \\
\text { combinations" }\end{array}$ & $\begin{array}{l}\text { There is no separate chapter for consolid } \\
\text { price; Goodwill is tested for impairment; S } \\
\text { and Combined Financial Statements; }\end{array}$ \\
\hline $\begin{array}{l}\text { NAS } 10 \text { "Grants and } \\
\text { others forms of } \\
\text { assistance" }\end{array}$ & $\begin{array}{l}\text { There are other requirements for the recognition of the grant as well as this standard does not cover non- } \\
\text { governmental grants. }\end{array}$ \\
\hline NAS 11 "Income tax" & $\begin{array}{l}\text { It is an opt } \\
\text { deferred ir }\end{array}$ \\
\hline $\begin{array}{l}\text { NAS } 12 \text { "Exchange } \\
\text { rates" }\end{array}$ & $\begin{array}{l}\text { nal currency and the primary economic environment; Missing } \\
\text { n a foreign entity"; }\end{array}$ \\
\hline $\begin{array}{l}\text { NAS } 13 \text { "Biological } \\
\text { assets" }\end{array}$ & $\begin{array}{l}\text { The concessionary agreements are missing; Model for assessment of biological assets is only cost } \\
\text { model; }\end{array}$ \\
\hline $\begin{array}{l}\text { NAS } 14 \text { "Investments in } \\
\text { associates and joint } \\
\text { ventures" }\end{array}$ & $\begin{array}{l}\text { Applies the fair value model in the evaluation of investments in associates or joint venture investments; } \\
\text { Lacks criteria which, if met, allow the entity not to prepare consolidated financial statements; Missing } \\
\text { requirements that clarify aspects of the implementation of the equity model or cost model in the } \\
\text { measurement of investments in associates and joint ventures; }\end{array}$ \\
\hline
\end{tabular}

There are no provisions in NASs which covers following sections of IFRS for SME: Additional Financial Instruments Issues; Liabilities and Equity; Share-based Payment; Employee Benefits; Hyperinflation; Related Party Disclosures.

\subsection{Table of Concordance - Differences between the NAS and Directive 213/34/EU}

The NASs were compared to the provisions of Directive 2013/34/EU. The spirit of the directive is to allow member states to define themselves the accounting treatments but it is mandatory to unify the presentation of financial statements as well as the notes of those statements. Analyzing all the differences arised from the concordance table, one can easily understand that those are all about disclosures or legal issues. These differences have, only in few cases, implications to NASs but this doesn't mean any immediate change to NASs. In these circumstances, when the differences between NAS and Dir 213/34/EU, were almost exclusively about the disclosures and not the accounting treatments, it can be said that in terms of accounting regulations in the EU is neutral the fact whether local NAS or IFRS SME will be adopted. Better harmonization with the Directive, after identifying the differences above, requires mostly legal amendments of the law on accounting and some modifications on discosures in the actual set of accounting and financial reporting.

\subsection{Readness and qualification of prepares of financial statements}

From the survey done on a sample of 381 accounting professionals, 141 of the questionnaires (37\%) were returned completed. Of those who answered the questions, 39 were certified auditors, 43 were certified public accountants, while 59 others were graduated in finance and accounting but employed by entities. The questionnaire was divided in three sections:

- The first section gathered information on demographic data for the entity as well as data for the preparers of the entity's financial statements;

- The second section was completely focused on gathering evidence of the degree of preparation and 
qualification of preparers to implement NASs

- The third section was completely focused on gathering evidence of the degree of readiness of the preparers in adopting IFRS for SMEs.

\section{The Processing of Demographic Data, Among others Showed that}

- There is a fair correlation between the size of the entity and the degree of preparation of preparers (large entities have employed or contracted more skilled people which have a better knowledge on NASs)

- Younger professionals, they were aware of IFRS for SMEs existence;

- Older professionals showed a greater resistance to make new changes in financial reporting;

- Professionals with international qualifications were in favor of the transition to IFRS for SMEs;

- In local entities, it was lower the interest of which set of financial reporting they were applying;

- In foreign entities or joint ventures, resulted higher the level of qualification of preparers;

\section{By Processing Data on the Preparation of Preparers in Regard of the Implementation of the Nas was Found that}

- In general, the financial statements were prepared for tax office purpose so preparers were keen to better know and implement fiscal legislation compared to the requirements of the set of financial reporting;

- They still need training and application guidance's materials on the implementation of the NASs;

- It is used only cost model (in local entities) to assess the elements of financial statements on reporting date as the preparers generally don't know how to apply the fair value model;

- It is used cost model and rarely fair value model (in foreign entities or joint ventures) when assessing the elements of financial statements because usually there is no any active market for and other alternative methods are not easily applicable (lack of application guidance);

- NAS 3 "Financial Instruments" is mostly not applicable and when it is used, there are a lot of difficulties in its interpretation. Furthermore, it is absolutely used only cost model;

- NAS 6 "Provisions and contingency" is almost unusable because the provisions are not recognized as an expense for tax purposes;

- The cost of borrowing for qualified assets is always capitalized and never as treated as period expenses as tha last one is not in accordance with the requirements of fiscal policy;

- In local entities, preparers do not know or do not use NAS 9 "Business combinations" or NAS 14 "Investments in associates and joint ventures";

\section{The Processing of Data on Preparers' Readiness for Adoption of IFRS for SMEs Showed that}

- Preparers of small and medium entities have very few knowledge or better to say nothing on IFRS for SMEs. It is a different sittuation in large entities; the preparers have an average level of knowledge on IFRS for SME's;

- Especially preparers in small and medium entities are not interested to face with radical changes to the set of financial reporting. They do not feel secure if they can succeed, at least for some time as they need a lot of trainings;

- Preparers of the large entities articulate that training is very important before transition to IFRS for SMEs but are generally in favor of its adoption;

- Regarding the option if they were in favor of full adoption of IFRS for SMEs or to a better compliance of NASs with the IFRS for SMEs, $84 \%$ of respondents were in favor of the second alternative;

- Generally preparers were against adopting full IFRS for SMEs for some of the following reasons: It is a new set that should be taught from the beginning (they haven't completely understood NASs yet); Some sections of IFRS for SMEs (6 of 34) are not relevant for Albania; Section of complex financial instruments is very difficult to implement; Since very few basic differences are to be changed to NASs, it comes simple for preparers to save NASs but reflecting the most relevant differences with IFRS for SMEs; Standardization of financial reporting do not concern to the local entities as long as they are not interested in foreign investors or foreign funds (96\% of local small and medium entities); They feel insecure about whether IFRS for SMEs once adopted will require much more additional work to comply with the requirements of fiscal legislation; 


\subsection{Users of financial statements of SMEs}

To understand who are the users of financial statements of small and medium-sized entities, was drafted another questionnaire that was distributed to 60 entities (managers / owners of these units as target group), 12 commercial banks (loan officers) and five leasing companies (leasing officers). That questionnaire was divided in two sections.

\section{From Processing the Demographic Data of the Entities Investigated, Regarding the Users of Financial Statements Resulted that}

- The users of financial statements of local entities, in the judgment of the managers / owners, are tax authorities, banks and while they, as the menagement of the entity, are very few interested;

- Users of financial statements of foreign entities or joint ventures, in the judgment of the managers / owners, are tax authorities, investors, banks and board of Directors;

- Users of financial statements are the same regardless of the size of the entity;

- Users of financial statements are the same regardless of the type of activity of the entity;

- There is a far correlation between education of managers / owners and their being real users of financial statements;

\section{The Processing of the Data Gathered from the the Second Section, in Regard of the Role and Importance of FS for Decision Making Procces of their Users, Showed that}

- In smaller entities, economic decisions do not rely on financial statements. Those are drafted almost exclusively for tax purposes (managers / owners make their decisions based on the data they receive from direct tracking of activity while banks, on their decision making for lending, heavily rely on physical checks of business activity of the entities as well as on direct contacts with the management of the entities);

- In the medium entities the interest for financial statements of is slightly higher (second tier banks require these statements when evaluate a credit file but the are still looking for sufficient disclosers and notes or other supporting evidence while managers / owners, as in small units mosity do not rely their decision making in the financial statements);

- Managers / owners do not support the decisions of internal control in the financial statements;

- Banks as user, raise the same problem; the entities prepare almost three different pairs of FS (one for the owners, one for the bank and the official one for tax office), which makes these statements less and less relevant for decision making;

- Banks, having no trust on true and fair statements, prepare themselves at least statement of cash flows and adjust the balance sheet and income at a rate of non confidence;

- Statements that present the greatest interest to users of financial statements are found to be income statement (for managers / owners), balance sheet, income statement and notes (for banks) and the whole set of statements (for tax purposes);

- As they do not know IFRS for SMEs, managers / owners are not able to answer which of the sets of reporting would be more appropriate (they have no information on the meaning and impact of accounting policies used when preparing financial statements);

- Commercial banks and leasing companies had made little effort to train their staff on NASs and no effort in terms of IFRS for SMEs training. Banks have their own policies and methodologies for lending decision making so the set of reporting financial information is not important to them;

\subsection{Economic context}

\subsubsection{Costs shifting toward IFRS for SMEs and its impact on business}

To understand more about the costs faced from the entities when adopting IFRS for SMEs comparing with the benefits that will flow from these costs, another questionnaire was developed with very few questions and addressed to the same sample selected as representative of users of FS. Questionnaire, as an annex to the main questionnaire, was drafted with only one section and totally focused on the analysis of cost / benefit. 


\section{The Processing of the Data Resulted as Following}

- Small entities are not ready to invest for other new changes in financial reporting because statements themselves do not improve the quality of their business decision. Generally these entities pay external suppliers for accounting services. They evaluate that a change in reporting would have at least an additional cost of 60 to 90 thousands lekë (400 - 600 euro) per year, which cost in their judgment does not bring any benefit;

- Medium entities, estimate approximately an additional cost of about 400 thousand lekë (3.000 euro) as an initial cost and an additional permanent cost of about 300 thousands lekë (something more than 2.000 euros) per year. In the initial cost they include the training of accounting department's staff, purchase of a new accounting software and at least one more qualified employee with a monthly wage of at least 20 to 25 thousand lekw (140 - 180 euros) higher;

- Medium entities, $8 \%$ of those investigated, are willing to invest in the transition to IFRS for SMEs. They require internationally standardized financial statements as their intention is to search for foreign investors;

- Medium entities, 3\% of those investigated, are willing to invest in the transition to IFRS for SMEs. They consider this shifting as a necessary intermediate step towards full IFRS implementation, as they aim to become a large entity in a 5-year period;

- Medium entities, $58 \%$ of those investigated, are not ready to invest in the transition to IFRS for SMEs. They consider this shifting is not relevant to the quality of their economic decision-making. Also they neither expect to be not financed by foreign funds nor has interest in foreign investors or even less intend to become a corporation in the medium future;

- Medium entities, $26 \%$ of those investigated, are not ready to invest in the transition to IFRS for SMEs. They consider this shifting not only an additional cost in training, software and new staff but also as another burden to comply with fiscal system requirements. They are neither willing nor interested to invest once again in their accounting to adjust it with that of tax office;

\section{Conclusions and Reccomandations}

After analyzing the findings presented in the previous chapter, naturally the main conclusion reached is that the decision for adoption of IFRS for SMEs is actually premature.

In technical terms, the differences between NASs and the relevant sections of the IFRS for SMEs are scarce and it's quite simple, possible and costless to integrate these differences into the current NASs. Also, remains the most appropriate option that of harmonizing NASs with IFRS for SMEs because part (6 sections) of this international standard is absolutely inapplicable in Albania.

The attitude of preparers was very crucial to reach the main conclusion. In circumstances when most of them still face difficulties in the implementation of the NASs, it would be premature to shift to another set of reporting. Remains still valid the alternative to harmonize NASs with IFRS for SMEs as this process comes easier for the preparers of FS. Should be an appropriate reccomandation that of starting with trainings far before adopting IFRS for SMEs.

But on the other hand it's the attitude of users that would determine the decision on IFRS for SMEs adoption. Even users, according to the questionnaires are in favor of the alternative of harmonizing NASs with the IFRS for SMEs for the reasons that were stated in the previous chapter. It's only tax office which analyze these statements when makes its decisions while banks and managers/owners rely their decisions on other informal information taken from daily activities of entities.

In the economic context, the findings ultimately support the second alternative, harmonizing NASs with IFRS for SMEs and not the full adoption of the latter. It would be a significant cost, especially for small entities and totally irreversible in terms of any benefit for these entities. As long as it does not improve the quality of decision-making, drafting financial statements is only a mandatory expense. Situation is somewhat different in medium entities, even in those of the upper threshhold, especially those with foreign shareholders or wholly foreign-owned. These entities are more inclined to invest in the transition to the IFRS for SMEs.

Another very significant conclusion is that of the impact of financial reporting culture. As noted by the questionnaire responses, in general culture of financial reporting is more oriented toward respecting fiscal rules and neglecting accounting standards.

Taking into consideration the attitude of preparers, users and all technical evaluation of the differences between NAS and IFRS for SMEs, the recommendation at the end of this paper is to to have a smooth transition toward IFRS for 
SMEs through the harmonization of existing NAS and then in a period of not less than 3 years to be re-assessed again the attitude of all stakeholders as well as all changes in the international arena of financial reporting.

\section{References}

Analoui, F. and Karami, A. (2003). Strategic Management in Small and Medium Enterprises. 1st edition. London, Great Britain: Thomson Learning.

Bryman, A. and Bell, E. (2007). "Business Research Methods." 2nd edition. New York, USA: Oxford University Press 2007.

Collis, J., Jarvis, R. and Skerratt, L. (2001). Size and the value of the audit. Accounting \& Business. 4 (10). 41-42.

European Commission. (2008). Putting small businesses first: Europe is good for SMEs, SMEs are good for Europe. [Booklet]. European Commission.

Fitzpatrick, M. and Frank, F. (2009). IFRS for SMEs: The Next Standard for U.S. Private Companies? Journal of Accountancy. 208 (6). 50-54.

IASB. (2010). Who we are and what we do. International Accounting Standards Board (IASB) and IASC Foundation (January 2010).

IASC Foundation Education. (2009). Training Material for the IFRS for SMEs. London: IASC Foundation Publications Department.

International Accounting Standards Board. (2009). International Financial Reporting Standards (IFRS) for Small and Medium-sized Entities (SMEs) by International Accounting Standards Board (IASB). London: IASB.

Lippitt, J. \& Oliver, B. (1983). Big GAAP, Little GAAP: Financial Reporting in the small business environment. Journal of Small Business Management.

Lungu, C. Caraiani, C. \& Dascalu, C. (2007). New Directions of Financial Reporting within Global Accounting Standards for Small and Medium-Sized Entities.

Munter, P.H., Anderson, S.R. and Mellentine, J. (2009). Issues In-Depth: A Closer Look at IFRS for SMEs. KPMG Department of Professional Practice. 09 (2). 1-17.

Neag, R., Masca, E., \& Pascan, I. (2009). Actual Aspects Regarding The IFRS For SME - Opinions, Nelson, M.W. (2003). Behavioral evidence on the effects of principles- and rules-based standards (commentary). Accounting Horizons. 17. 91-104.

Nicoleta, P.D., Victoria, B., Mariana, F. (2009). Standards, Rules or Principles based accounting regulation. Journal of Faculty of Economics, III, 1125-1131.

Pacter, P. Standards and SMEs: who, what, when and why? Accounting \& business WCOA special edition. 31-33.

/2004/804/essentials/p34.htm> [Retrieved 23-03-2010 at 5pm-6pm]

Taylor, D.W. (2009). Costs-benefits of adoption of IFRSs in countries with different harmonization histories. Asian Review of Accounting. 17 (1). 40-58 